ISSN 0258-7122

Bangladesh J. Agril. Res. 36(2) : 279-284, June 2011

\title{
EFFICACY OF SEDOMIL 72 WP AND RECOZEB 80 WP IN CONTROLLING RED RUST OF TEA
}

\begin{abstract}
M. S. ISLAM ${ }^{1}$ AND M. ALI ${ }^{2}$
Abstract

An experiment was conducted for two years to find out the efficacy of two fungicides Sedomil 72 WP (Mancozeb) and Recozeb 80 WP (Mancozeb + Metalaxyl)@1,1.5, 2.0, and $2.5 \mathrm{~kg} / \mathrm{ha}$ in controlling red rust disease (Cephaleuros parasiticus) of tea. in both the years, Sedomil 72 WP and Recozeb 80 WP inhibited disease severity and disease progress. Among the treatments, the highest reduction in PDI was obtained with $2.5 \mathrm{~kg} / \mathrm{ha}$ of the both fungicides. During 2008, Sedomil 72 WP showed 93.28\% and Recozeb 80 WP showed $91.04 \%$ efficacy with the dose of $2.5 \mathrm{~kg} / \mathrm{ha}$ of both fungicides, while it was $91.40 \%$ of both with same dose during 2009. In case of the dose of $2.0 \mathrm{~kg} / \mathrm{ha}$ of both the fungicides caused disease reduction more than $80 \%$, which is significantly similar to the dose of $2.5 \mathrm{~kg} / \mathrm{ha}$. Decreasing trend in disease infection was observed from the spray to final sprays of both the fungicides for all doses. The overall result suggests that the use of Sedomil $72 \mathrm{WP}$ or Recozeb $80 \mathrm{WP}$ may provide an economic advantage alone with $2.0 \mathrm{~kg} / \mathrm{ha}$.
\end{abstract}

Keywords: Efficacy of Sedomil 72 WP, Recozeb 80 WP, red rust of tea.

\section{Introduction}

About 380 fungal and I algal diseases have so far been recorded in tea all over the world. The disease, spectrum of Bangladesh tea consists of I algal disease, 18 fungal diseases and few epiphytes (Sana, 1989). These diseases are hitherto the most common. Red rust is a predominant stem disease in tea garden caused by an alga, Cephaleuros parasiticus Karst (Sana, 1989; Huq et al., 2007). The disease appears sporadically every year in most of the tea gardens of Bangladesh causing different degrees of losses. In Bangladesh, about 8-25\% tea estates are affected by this disease (Sana. 1989). When tea plants are affected by red rust disease, the leaves become yellow or white variegated with green. The disease is most common in young tea, old tea bushes in seed baries and unthrifty tea sections. The alga can infect the branches at any stage of growth. Once the branch is infected, the alga remains latent for a year. In the following year depending on the first rain, fruiting bodies of the pathogen are produced (Huq et al., 2007). In extreme cases, red rust causes severe damage to young tea plants by killing stem tissues in patches. The alga produces minute spores, especially on the stems of tea plants. Red rust can attack both young and old tea plants under adverse

${ }^{1 \& 2}$ Division of Plant Pathology, Bangladesh Tea Research Institute (BTRI), Srimangal3210, Bangladesh. 
conditions of soil and climate. The predisposing factors of the disease mainly are poor fertility, alkalinity and lack of aeration of the soil, hard pan, inadequate or complete absence of shade, drought and water logging (Sarmah, 1960). The disease is widely distributed in the zones of North-East India, Srilanka, and Bangladesh (Sana, 1989). Due to attack by the disease, plants become very weak. New shoots those are sprouted are very thin. Dry weight content in these shoots are less resulting the crop loss.

Available literatures in relation to fungicidal control of the disease are very limited in Bangladesh. Chaudhury and Ahsan (1976) reported that healthy leaves of clones and seedlings contain more nitrogen and potash than that of the red rust infected ones. The tea yield was negatively and nearly correlated with severity of red rust disease (Huq et al., 2010). The effective treatment for controlling the disease was application of the Potash fertilizer (MP). which was followed by foliar spray with Copper Hydroxide and Carbendazirn (Huq et al., 2010). Carbendazim, Copper oxychioride, Copper hydroxide. Hexaconazole, Propiconazole based fungicides were approved for controlling the disease in Bangladesh (Huq et al.. 2007). Recently Mancozeb and Mancozeb Metalaxyl were introduced to control different tea diseases in Bangladesh. To overcome this alarming situation, an effective fungicide with an appropriate dose is required to be explored. Therefore, the present study was undertaken to find out the optimum dose (s) of the two fungicides in controlling the disease.

\section{Materials and Method}

The field experiment was conducted at the main experimental farm of Bangladesh Tea Research Institute (BTRI) during 200\$ and 2009. Two fungicides, namely Sedomil 72 WP (Mancozeb) and Recozeb 80 WP (Mancozeb + Metalaxyl) each with four doses constitute the treatments. The fungicides were applied 1.0. 1.5, 2.0, and $2.5 \mathrm{~kg} / \mathrm{ha}$. The control plots were sprayed similarly with plain water. The unit plot size was $7.15 \mathrm{~m} . \times 4.2 \mathrm{~m}$. The disease was allowed to develop naturally. After first monsoon, when typical symptom of the disease was observed, the treatments were applied to the experimental units. The fungicides were mixed with water $(1000 \mathrm{t} / \mathrm{ha})$ and applied directly to the stem and branches of the tea bushes. The fungicides were applied four times at 15 days interval starting from the appearance of the disease. The experiment was laid out in a Complete Randomized Block Design (RCBD) with three replications. Weeding, application of insecticides, tipping and other necessary intercultural operations were done as and when required. Disease incidence was recorded at 7 days after fungicidal application following 0-5 scale (Martins et al., 1988). 


\begin{tabular}{|c|c|}
\hline Infection (\%) & Grade/Scale \\
\hline Nil & 0 \\
\hline $1-20$ & 1 \\
\hline $21-40$ & 2 \\
\hline $41-60$ & 3 \\
\hline $61-80$ & 4 \\
\hline$>80$ & 5 \\
\hline
\end{tabular}

Infection (\%) means the intensity of sporulation of the algae appeared on the stem and branches. The severity of the disease was expressed in percent disease index (PDI), which was computed following a standard formula as described below (Singh, 2000).

Percent Disease Index $(\mathrm{PDI})=\frac{\text { Sum of all disease ratings }}{\text { Total number of ratings } \mathrm{x} \text { maximum disease rating }} \times 100$

Data were subjected to analyses by MSTAT computer programme. Mean separation was done by DMRT.

\section{Results and Discussion}

The results of the experiment are summarized in Table 1. The fungicides significantly reduced the disease severity over control irrespective of doses during both the cropping years. The progress of the disease was inhibited for fungicide spray at different intervals (Fig. $1 \& 2$ ). All treatments with fungicides caused significant reduction in severity of red rust in terms of PDI. In 2008 and 2009, the lowest infection was observed both in Mancozeb and Mancozeb + Metalaxyl treated plots when the dose was $2.5 \mathrm{~kg} / \mathrm{ha}$. They caused 93.28 and $91.04 \%$ reduction in PDI over the control in 2008, respectively, while it was $91.40 \%$ of the both in 2009 (Table 1).

The efficacy of second highest doses $(2.0 \mathrm{~kg} / \mathrm{ha})$ of both the fungicides fur both the years was found to be statistically similar. They caused more than $80 \%$ reduction in PDI over the control in 2008 and 2009 (Table 1). Table I also showed that PDI was gradually reducing with the low doses of both the fungicides. 
Table 1. Efficacy of diflbrent doses of two fungicides in controlling red rust disease of tea.

\begin{tabular}{l|l|l|l|l}
\hline \multirow{2}{*}{ Treatments } & \multicolumn{3}{c|}{2008} & \multicolumn{2}{c}{2009} \\
\cline { 2 - 6 } & PDI & $\begin{array}{c}\text { \% Reduction in } \\
\text { PDI over control }\end{array}$ & PDI & $\begin{array}{l}\text { \% Reduction in } \\
\text { PDI over control }\end{array}$ \\
\hline $\mathrm{T}_{1}=$ Control & $67 \mathrm{a}$ & 00 & $64 \mathrm{a}$ & 00 \\
Sedomil72WP@ & & & & \\
$\mathrm{T}_{2}=@ 1.0 \mathrm{~kg} / \mathrm{ha}$ & $34 \mathrm{~b}$ & 49.25 & $32.5 \mathrm{~b}$ & 49.21 \\
$\mathrm{~T}_{3}=1.5 \mathrm{~kg} / \mathrm{ha}$ & $24.5 \mathrm{bc}$ & 55.97 & $22.5 \mathrm{c}$ & 64.84 \\
$\mathrm{~T}_{4}=@ 2.0 \mathrm{~kg} / \mathrm{ha}$ & $13 \mathrm{de}$ & 80.59 & $12.5 \mathrm{~d}$ & 80.46 \\
$\mathrm{~T}_{5}=@ 2.5 \mathrm{~kg} / \mathrm{ha}$ & $4.5 \mathrm{e}$ & 93.28 & $5.5 \mathrm{~d}$ & 91.40 \\
$\mathrm{Rec}=2 \mathrm{~b} 80 \mathrm{WP}$ & & & & \\
$\mathrm{T}_{6}=1.0 \mathrm{~kg} / \mathrm{ha}$ & $34 \mathrm{~b}$ & 49.25 & $32.5 \mathrm{~b}$ & 49.21 \\
$\mathrm{~T}_{7}=1.5 \mathrm{~kg} / \mathrm{ha}$ & $22.5 \mathrm{~cd}$ & 66.41 & $21.5 \mathrm{c}$ & 66.40 \\
$\mathrm{~T}_{8}=2.0 \mathrm{~kg} / \mathrm{ha}$ & $13.25 \mathrm{de}$ & 80.22 & $12.5 \mathrm{~d}$ & 80.46 \\
$\mathrm{~T}_{9}=2.5 \mathrm{~kg} / \mathrm{ha}$ & $6.0 \mathrm{e}$ & 91.04 & $5.5 \mathrm{~d}$ & 91.40 \\
\hline
\end{tabular}

Means within the column with same letter(s) do not differ significantly by DMRT at $\mathrm{p}=0.05$.

Regarding the different intervals $(15,30,45$ days) of sprayings of fungicides, it was observed that without fungicides application, disease intensity gradually increased. PDI was gradually increased along with increasing the spraying interval of control, while it was gradually decreased with the increased doses and spraying interval of both fungicides (Fig. $1 \& 2$ ). It indicates that when the disease was first appeared in the field, the degree of severity was increased gradually after 15 ( $22^{\text {nd }}$ spray), $30\left(3^{\text {rd }}\right.$ spray), and 45 days ( $4^{\text {th }}$ spray) without using fungicides. It was also seen that after the final application of fungicides, intensity of disease development was in decreasing trend. Decreasing trend in disease infection was observed from the $1^{\text {st }}$ spray to final sprays of both the fungicides with respective doses. It indicates that after $1^{\text {st }}$ application of fuingicides, the zospores of the pathogen are killed. The latent spores also become very weak. After $4^{\text {th }}$ application of fungicides, the latent spores cannot express the symptom of the disease. 


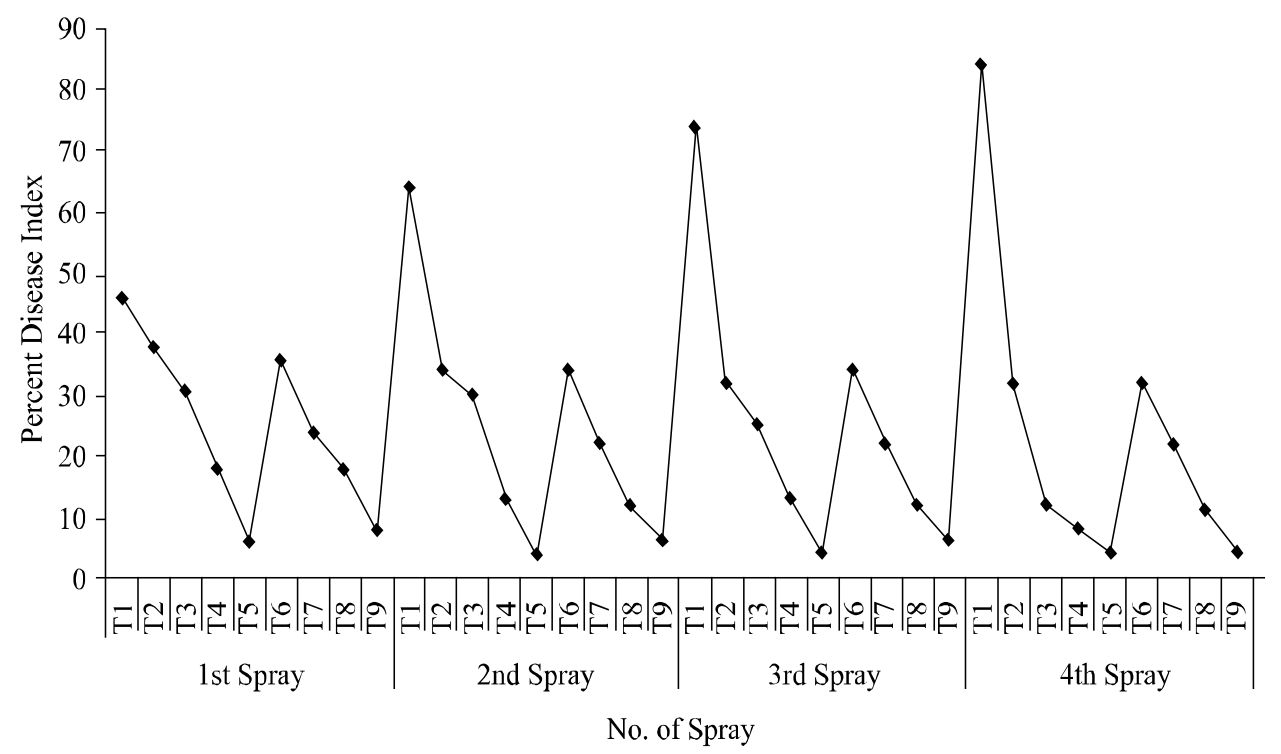

Fig. 1. Effect of different doses of fungicides on the development of red rust disease during 2008.

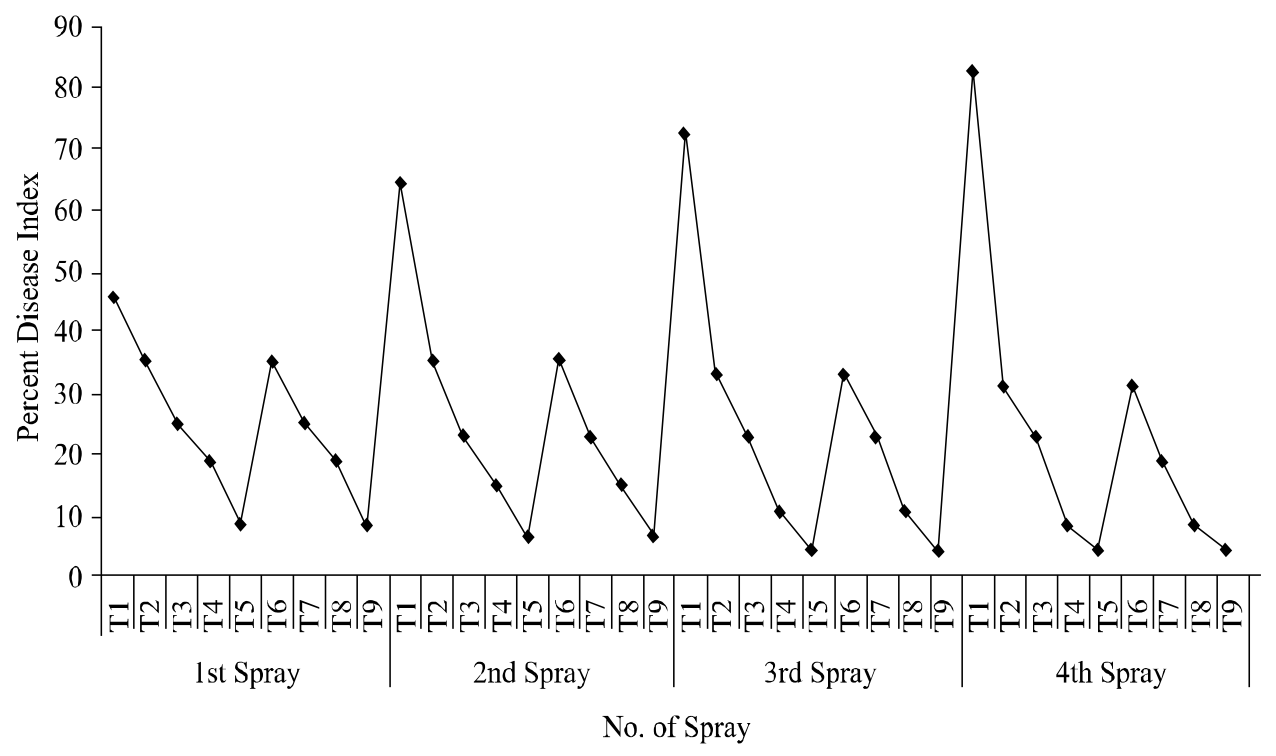

Fig. 2. Effect of different doses of fungicides on the development of red rust disease during 2009.

From the results of two years' study, it is indicated that all the doses of Sedomil 72 WP and Recozeb 80 WP caused significant reduction of the severity of red rust disease in tea as compared to control. Under the present investigation, 
both the fungicides @ $2.5 \mathrm{~kg} / \mathrm{ha}$ showed the highest performance followed by 2.0 $\mathrm{kg} / \mathrm{ha}, 1.5 \mathrm{~kg} / \mathrm{ha}$, and $1.0 \mathrm{~kg} / \mathrm{ha}$. As per literature, whenever the protective fungicide is sprayed, it goes contact to the spores and kills them. The causal algae of the disease can remain latent within the stem. After first monsoon when the spores of algae expose (Huq et al., 2010). Sedomil 72 WP and Recozeb 80 WP may have the ability to kill the exposed spores and suppress the disease.

The overall result suggests that the use of Sedomil 72 WP and Recozeb 80 WP @ $2.5 \mathrm{~kg} / \mathrm{ha}$ and $2.0 \mathrm{~kg} / \mathrm{ha}$ are equally effective in controlling the disease. $2.0 \mathrm{~kg} / \mathrm{ha}$ of both the fungicides may be recommended against the red rust disease of tea.

\section{References}

Chaudhury. S. H. and Q. Ahsan. 1976. Studies on the chemical composition of normal Vs variegated tea leaves affected by red rust disease. Tea J. Bangladesh 12(1): 5-Il

Huq. M., M. Ali and M. S. Islam. 2007. Red rust disease of tea and its management. Memorandum no. 1. Bangladesh Tea Research Institute, Srimangal: pp. 1-8

Huq, M., M. Ali and M.S. Islam. 2007. Approved Fungicides and Weedicides for Bangladesh Tea. Cireular No. 119. Bangladesh Tea Research Institute. Srimangal: pp. 1-6

Huq. M., M. All and M.S. Islam. 2010. Efficacy of muriate of potash and foliar spray with fungicide to control red rust disease (Cephaleuros parasiticus). Bangladesh .1. Agril. Ret. 35(2): 273-277.

Martins, O. M.. A. Takasu and J.B.R. Schneider. 1988. Virulence of biovars I and 3 of Pseudomonas solanacearam towards tomato. Fitopathologica Brasileira 13(3): 249252.

Sana, D.L.. 1989. Tea Science. Ashrafia Boi Char. 36. Bangla Bazar, Dhaka, pp. 96-99.

Sana. D.L.. 1989. Tea Science. Ashrafla Boi Ghar, 36, Bangla Bazar, Dhaka, pp. 224-226.

Sarmah, K. C. 1960. Red rust Cephaleuros parasitiaus Karst. Disease of tea and associated crops in North-East India. Mennorandum no. 26: 44-46.

Singh. R.S. 2000. Assessment of disease incidence and loss. Introduction to Principles of Pathology. $3^{\text {rd }}$ edition, $328 \mathrm{pp}$.

Tomlin, CDS. 1997. The pesticide manual. Eleventh edition. Published by British Crop Protection Council (BCPC), UK. pp. 76 1-762. 